\title{
Perception of Elementary Education and Art Education Teacher Candidates towards the Aesthetic Concept
}

\author{
Hatice Kübra Ozalp \\ Ahmet Kelesoglu Education Faculty, Necmettin Erbakan University, Turkey
}

Copyright $\mathrm{C} 2018$ by authors, all rights reserved. Authors agree that this article remains permanently open access under the terms of the Creative Commons Attribution License 4.0 International License

\begin{abstract}
The aim of this research is to determine and compare the perceptions (metaphors) related to the "aesthetic" concept of the students, studying in the Primary Education and Pre-School Education Departments which take part in the Department of Elementary Education and in the Art Education Department that takes part in the Department of Fine Arts Education in Education Faculties. The data collection process of the research was carried out with the voluntary participation of the 3rd and 4th year students of the Departments of Primary Education, Pre-School Education and Art Education. The study group of the research consisted of a total of 263 teacher candidates. In order to determine the perception about the "aesthetic" concept metaphorically, participants were asked to complete the sentence "Aesthetic is like ........ because ........." The data obtained in this direction were analysed by qualitative and quantitative data analysis techniques. Metaphors generated by the participants were divided into categories after analysing with the content analysis method from qualitative research methods in terms of their common features. As a result of the analyses made, it has been observed that students of Departments of Art Education, Pre-school Education and Primary Education emphasize that the aesthetic concept is a concept based on pleasure. The quality of changing and beautifying the environment and the case that is regarded as a surgical intervention of the aesthetic concept were the least emphasized features by the students.
\end{abstract}

Keywords Art Teaching, Elementary Education, Metaphor, Aesthetic Education.

\section{Introduction}

Metaphor is an important tool for determining the direction and degree of perception by setting off from mental images. It is to reveal what is meant to be in the background as a result of interpretation or perception of a stand-alone object or phenomenon.

[22] regards metaphors as a matter of thought and action rather than a language issue, in other words, a metaphor is a concept based on experience and creates similarities between different fields. The essence of metaphor is a kind of understanding and experience. Metaphors, generated by resemblance to lived experiences are a new way of perceiving the world. In this sense, metaphor is a concept that requires creativity. [8] describes metaphor as a reflection of cognitive inner appearance and ultimately, an element that allows the understanding of how communication phenomena in the world are perceived by a person. According to [39], metaphor is a powerful mental instrument for an individual to understand and explain a high level of abstract, complex, or theoretical phenomenon. It emphasized that the use of metaphors in understanding an abstract phenomenon allows an individual to consider a phenomenon in his/her mind as another phenomenon [22, 32]. Metaphors are the most valuable tools of perception. They enable a conscious perception to take place beyond one's own individual feelings since all the thoughts, memories and inferences arouse the network by comparing the viewer's experience to another experience [23]. Conscious perception and individual sensation are necessary for understanding and appreciation of an artwork. This brings the aesthetic perception with it.

Aesthetic in art is used with the meaning of perception of emotion. Searching for beauty and getting pleasure form the basis of aesthetic. An individual's appreciation of art and the value of an artwork means aesthetic perception.

[24] describes the aesthetic research as a process of appreciation and valuation of art by students. According to [37], aesthetic reality is a human related reality. It is more concerned with the things what people see, feel or experience. [31], on the other hand, mentions that aesthetic is rather a communication that aims to give the audience practical and theoretical information. When considered in this respect, John Dewey's aesthetic description comes to mind. There is personal experience on J. Dewey's basis of thought. Aesthetic experience is an important element in empathizing with other objects, self-understanding, and digesting other experiences [18]. Experience is needed to get very different forms of information. For this reason, experience is required for aesthetic knowledge as well. 
Etymologically, aesthetic can be evaluated as the experience of common feelings [25]. In this sense, when it is accepted as a reflection of the emotions felt by man, aesthetic is far from being a quality that exists on the object itself. The object is now becoming a psychological thing. [34] emphasizes that aesthetic should not give a person anything other than important opportunities to take him to deep feelings and great emotions. In order to get feelings out of the man connected to the material, it is first necessary to change his nature. The appearance of the things is the work of man. The soul that is fed on appearance does no longer enjoy what it takes; it enjoys what it does. This separates the material at the point of truth and appearance from each other. Appearance is the reality that exists in the material. Truth means, on the other hand, getting to the core and reaching the aesthetic reality. In this direction, [15] also evaluates seeing images out of objects and designing images for objects in the same process. It is the power of man and design to create images that aesthetic thinking face in relation to objects. The interpretation of objects is the correspondence of previously experienced situations in the mind. A person can understand an artwork better when he/she transforms everyday experience into aesthetic experience or lives an artistic experience.

Experience aims to enable not only to understand the concept of aesthetic experience but also to understand a person's relationship with artworks [33]. He states that cognitive activities such as reading poetry, listening to music, watching a view are cognitive actions conducted to mean the whole world, and in fact, all cognitive actions cannot be aesthetic actions basically. In order to have an aesthetic experience, it is necessary to have environments such as satisfaction and appreciation. For this reason, the actual experience is not realised from the object itself but as a result of careful and cognitive examination. In the literature, on the other hand, [26]; [10]; [12]; [15]; [19]; [13]; [28]; [7]; [38] and [23] are among the studies that intensely emphasize the importance of aesthetic experience in understanding aesthetic. Understanding an artwork in art education is a case based on perception. Metaphor, an effective method in perceptual analysis, is regarded as a method that can be used in analyzing the perception of art concepts. [8] mentions about two stages in the classification of senses for visual arts. The first is an understanding of what kind of relation there is between the affective forms and other forms. The other is about the analysis of the relationship between aesthetic judgment and the concepts we recognize and encounter in the world. According to [14]'s perceptual metaphor theory, people can understand and classify the phenomena that they see, hear, and feel better than the phenomena that they cannot see, hear, or feel. For this reason, people systematically try to conceptualize abstract concepts such as time, life, and emotions with concrete concepts. The fact that aesthetic is an abstract concept in art education requires the investigation of concrete facts to explain it. For this reason, metaphor is the determiner in the analysis of the perception that occurs with experience in the field of art education, and the extraction of cognitive information. There are a limited number of studies on metaphors in the field of art education. [9]; [30]; [29]; [20]; [35]; [21]; [1]; [11]; [17]; [6]; [16] and [4] are some of the studies on the necessity of using metaphors in education and fine arts education. However, besides the field of art education, no research, conducted on the metaphor analysis related to the concept of aesthetic in the field of Elementary Education was found.

In this direction, the main purpose of the study is to reveal and compare the aesthetic concept perceptions of the teacher candidates who took a course related to the visual arts and studying in the Departments of Elementary Education and Art Education. Within the framework of this general objective, answers to the following questions were sought; "How are students' perceptions related to the aesthetic concept?", and "What are the differences in the "aesthetic" concept perceptions of the students studying in the Elementary Education Department and in the Art Education Department?"

\section{Method}

The phenomenological approach from qualitative research methods constitutes the model of the research. This approach aims to reveal how a concept is perceived and how experiences influence the perception. According to [27], the phenomenological approach is suitable for studying effective, emotional, and often intense human experiences. In his work on explanation of examples in different fields of art with a metaphoric language, as the world of art is becoming more diverse, [36] states that the use of the conceptual metaphor theory in researches is an appropriate method for revealing which art forms are perceived by what kind of audiences and how.

\subsection{Working Group}

Table 1. Demographic Characteristics of Participants

\begin{tabular}{|c|c|c|c|c|c|}
\hline $\begin{array}{c}\text { Participant } \\
\text { Type }\end{array}$ & f & (\%) & $\begin{array}{c}\text { Demographic } \\
\text { Feature }\end{array}$ & f & $(\%)$ \\
\hline \multirow{2}{*}{$\begin{array}{c}\text { Art } \\
\text { Education } \\
\text { Department }\end{array}$} & \multirow[b]{2}{*}{46} & \multirow[b]{2}{*}{$(17,4)$} & Female & \multirow{2}{*}{$\begin{array}{c}39 \\
7\end{array}$} & \multirow{2}{*}{$\begin{array}{l}(84,7) \\
(15,2)\end{array}$} \\
\hline & & & Male & & \\
\hline \multirow{2}{*}{$\begin{array}{l}\text { Pre-school } \\
\text { Education } \\
\text { Department }\end{array}$} & \multirow[b]{2}{*}{159} & \multirow[b]{2}{*}{$(60,4)$} & Female & \multirow{2}{*}{$\begin{array}{c}103 \\
56\end{array}$} & \multirow{2}{*}{$\begin{array}{l}(64,7) \\
(35,2)\end{array}$} \\
\hline & & & Male & & \\
\hline \multirow{2}{*}{$\begin{array}{c}\text { Primary } \\
\text { Education } \\
\text { Department }\end{array}$} & \multirow[b]{2}{*}{58} & \multirow[b]{2}{*}{$(22)$} & Female & \multirow{2}{*}{$\begin{array}{c}54 \\
4\end{array}$} & \multirow{2}{*}{$\begin{array}{c}(93,1) \\
(6,8)\end{array}$} \\
\hline & & & Male & & \\
\hline
\end{tabular}

Participants of the study consists of 3rd and 4th grade students studying in the Primary Education and Pre-School Education Departments of Elementary Education and 3rd and 4th grade students studying in the Art Education 
Department of Necmettin Erbakan University, Ahmet Keleşoğlu Education Faculty in the 2017-2018 Education year, Spring Semester.

A total of 263 people consisting of $67(25,4 \%)$ male and $196(74,5 \%)$ female students participated in the research. The distribution of the students according to their departments is as follows: $46(17,4 \%)$ students from the Art Education Department, 159 students $(60,4 \%)$ from the Pre-school Education Department and 58 (22\%) students from the Primary Education Department participated in the research. $39(84,7 \%)$ female and 7 $(15,2 \%)$ male students from the Art Education Department, $103(64,7 \%)$ female and $56(\% 35,2)$ male students from the Pre-school Education Department, and 54 (93,1\%) female and $4(6,8 \%)$ male students from the Primary Education Department participated in the study.

\subsection{Data Collection Tools}

In order to reveal the perceptions of the participants about the concept of "aesthetic", a form consisting of the sentence "Aesthetic is like.............., because............... " was used as a data collection tool.

\subsection{Collection of the Data}

In order to reveal the metaphors participants have about the concept of "aesthetic" they were asked to complete the "Aesthetic ............is like, because............." sentence. For this purpose, teacher candidates were given a blank form with the sentence written at the top of the page, and they were asked to express their thoughts by using this sentence and concentrating only on a single metaphor. Metaphors are used as a method to understand the perception of a concept in educational researches. Flannery (1991) argues that the only way to understand our experiences is to relate the things we know to the unknown, cited, [19]. In this research, where metaphors were used as a research tool, the concept of "like" was used to associate the link between the subject and the source of the metaphor more clearly. By giving place to the concept of "because" here, participants were asked to provide a rationale or logical basis for their own metaphors.

\subsection{Analysis of the Data}

The analysis of the data was carried out by coding and sorting the metaphors developed by the participants, compiling the metaphor images, developing categories, and interpreting these categories by means of content analysis. In the stage of category development, the metaphorical images generated by the participants were basically examined in terms of their common characteristics regarding the concept of "aesthetic". The expert examination or expert opinion, which is one of the strategies mentioned by [27], was applied for the internal validity and credibility of the study. The data obtained in this direction were analysed by two experts together with the researcher, and the categories were formed after the collective opinion was provided at the end of the analysis.

\section{Findings and Comments}

According to the general findings obtained in this research, teacher candidates studying in the Elementary Education Department and Art Education Department of the Faculty of Education generated a total of 219 valid metaphors related to the concept of aesthetic. In this section, each metaphor image, produced by the participants was analyzed for the subject of the metaphor and the relationship between the subject and the source of the metaphor. [13] states that the source and the target must be clearly distinguishable when determining if the metaphor is clearly related to the situation or not. Categories should be created by determining which phenomena and associations the metaphor corresponds to according to the impact area of the source. In this direction, each metaphor corresponding to the aesthetic concept in mind was associated with a theme and a total of 9 different conceptual categories have been created. Table 2 contains the classification properties of the categories compiled during the category development phase.

Table 2. Properties Used in the Classification of Generated Metaphors

\begin{tabular}{l} 
Aesthetic concept emphasizing the beauty in the nature with \\
order, peace and harmony \\
- Everything that is natural \\
- The harmony in the unity and solidarity on the earth \\
- Nature is visually beautiful \\
\hline Aesthetic concept emphasizing the expression of emotions \\
within a person \\
-Reflect the inner beauty of a person \\
-Expression \\
-Reflection of good feelings \\
\hline The relative aesthetic concept that changes according to the \\
person \\
-Change from person to person \\
-Change from age to age \\
\hline Aesthetic concept based on feeling pleasure \\
-Activate pleasant sentiments \\
-Arouse the feeling of pleasure \\
\hline Aesthetic concept accepted as a science of beauty \\
-Investigate the beauty in art \\
-Search for the beauty \\
\hline The aesthetic concept that gives the person a different \\
perspective \\
-Realize the beauty \\
-Gain the ability to predict \\
\hline Aesthetic concept that changes and beautifies the environment \\
-Show something different from it is \\
-Make a bad situation elegant, beautify it \\
\hline Aesthetic concept bearing a vital importance \\
-Add vitality to life \\
\hline Aesthetic concept as a surgical intervention \\
-Change a disliked physical property \\
\hline
\end{tabular}




\subsection{General Findings}

After the examination of the phenomena that the 263 students who participated in the research visualized in their minds, a total of 219 valid metaphors that teacher candidates studying in the Elementary Education Department and the Art Education Department of the Faculty of Education produced in relation with the concept of aesthetic were classified. As a result of the classification, metaphors were categorized as follows; aesthetic concept emphasizing the beauty in the nature with order, peace and harmony, aesthetic concept emphasizing the expression of emotions within a person, the relative aesthetic concept, changing according to the person, aesthetic concept based on feeling pleasure, aesthetic concept accepted as a science of beauty, aesthetic concept that gives the person a different perspective, aesthetic concept that changes and beautifies the environment, aesthetic concept bearing a vital importance and aesthetic concept accepted as a surgical intervention. The metaphors, included in the created categories are presented in the following tables according to the student numbers and the departments they are in.

Table 3. Distribution of Categories According to Departments

\begin{tabular}{|c|c|c|c|c|c|c|}
\hline \multirow[t]{3}{*}{ Categories } & \multicolumn{6}{|c|}{ Departments } \\
\hline & \multicolumn{2}{|c|}{ Art Education } & \multicolumn{2}{|c|}{$\begin{array}{l}\text { Pre-school } \\
\text { Education }\end{array}$} & \multicolumn{2}{|c|}{$\begin{array}{c}\text { Primary } \\
\text { Education }\end{array}$} \\
\hline & $\mathrm{f}$ & $\%$ & $\mathrm{f}$ & $\%$ & $\mathrm{f}$ & $\%$ \\
\hline $\begin{array}{l}\text { Aesthetic concept emphasizing the beauty in the nature with order, peace } \\
\text { and harmony }\end{array}$ & 7 & 15,9 & 26 & 16,8 & 7 & 12,2 \\
\hline Aesthetic concept emphasizing the expression of emotions within a person & 1 & 2,2 & 18 & 11,6 & 6 & 10,5 \\
\hline The relative aesthetic concept that changes according to the person & 3 & 6,8 & 24 & 15,5 & 4 & 7 \\
\hline Aesthetic concept based on feeling pleasure & 22 & 50 & 33 & 21,4 & 18 & 31,5 \\
\hline Aesthetic concept accepted as a science of beauty & 7 & 15,9 & 12 & 7,7 & 11 & 19,2 \\
\hline The aesthetic concept that gives the person a different perspective & 3 & 6,8 & 9 & 5,8 & 4 & 7 \\
\hline Aesthetic concept that changes and beautifies the environment & - & 0,4 & 24 & 15,5 & 3 & 5,2 \\
\hline Aesthetic concept bearing a vital importance & 1 & 2,2 & 5 & 3,2 & 3 & 5,2 \\
\hline Aesthetic concept as a surgical intervention & - & 0,4 & 3 & 1,9 & 1 & 1,7 \\
\hline Total & 44 & 100 & 154 & 99,4 & 57 & 99,5 \\
\hline
\end{tabular}

When we look at the distribution of the categories formed by the generated metaphors according to the departments in Table 3, it is observed that the students of the Art Education Department emphasized the aesthetic concept which is based on feeling pleasure the most with $22(50 \%)$ repeats. Beside this, it is seen that the second most emphasized categories are the aesthetic concept emphasizing the beauty in the nature with order, peace and harmony and the aesthetic concept accepted as a science of beauty with $7(15,9)$ repeats. The categories of the relative aesthetic concept that changes according to the person and the aesthetic concept that gives the person a different perspective take part with a rate of $3(\% 6,8)$. The categories of the aesthetic concept emphasizing the expression of emotions within a person and the aesthetic concept bearing a vital importance are at the minimum rate with $1(\% 2,2)$ repeat. There were no metaphors generated in the categories of the aesthetic concept that changes and beautifies the environment and the aesthetic concept as a surgical intervention. It is observed that the students of the Pre-school Education Department emphasized the aesthetic concept based on feeling pleasure the most with $33(21,4 \%)$ repeats. The Aesthetic concept emphasizing the beauty in the nature with order, peace and harmony has been the second most emphasized category with a rate of $26(\% 16,8)$ repeats. It has been observed that the categories of the aesthetic concept that changes and beautifies the environment and the relative aesthetic concept that changes according to the person were emphasized at a rate of 24 $(\% 15,5)$ repeats. It is seen that the category of the aesthetic concept emphasizing the expression of emotions within a person has been emphasized with $18(\% 11,6)$ repeats. 12 $(7,7 \%)$ metaphors were generated in the category of the aesthetic concept accepted as a science of beauty. The number of $9(5,8 \%)$ repeats can be seen in the category of the aesthetic concept that gives the person a different perspective. It is seen that the category of the aesthetic concept bearing a vital importance with a repeat rate of 5 $(\% 3,2)$ and the category of aesthetic concept as a surgical intervention with a repeat number of $3(\% 1,9)$ are the categories with the least number of metaphors. The categories of the aesthetic concept based on feeling pleasure with a rate of $18(\% 31,5)$ and the aesthetic concept accepted as a science of beauty with a rate of 11 $(\% 19,2)$ have been emphasized in the first place among the metaphors generated by the students studying in the Primary Education Department. 7 (12, 2\%) metaphors were generated in the category of aesthetic concept 
emphasizing the beauty in the nature with order, peace and harmony. It can be seen that the aesthetic concept emphasizing the expression of emotions within a person category has got a repeat number of $6(6,5 \%)$. The repeat numbers of the aesthetic concept that gives the person a different perspective and the relative aesthetic concept that changes according to the person are both $4(7 \%)$. In the same way, it can be seen that the aesthetic concept bearing a vital importance category and the aesthetic concept that changes and beautifies the environment category both have equal repeat numbers with a rate of $3(5,2 \%)$. Finally, the aesthetic concept as a surgical intervention category has been the least emphasized category with a repeat rate of 1 $(1,7 \%)$. The distribution of the metaphors generated in the research according to the categories and the departments is given in the table below.

Table 4. Distribution of the Generated Metaphors by Categories

\begin{tabular}{|c|c|}
\hline \multirow[t]{2}{*}{ Departments } & \multirow[t]{2}{*}{ Metaphors by Categories $(n=219)$} \\
\hline & \\
\hline $\begin{array}{l}\text { Art Education } \\
\text { Department }\end{array}$ & $\begin{array}{l}\text { A natural thing } 1 \text {, a sunset view } 1 \text {, the beautiful and the ugly } 1 \text {, the world } 1 \text {, a colourful butterfly } 1 \text {, a tree } 1 \text {, the } \\
\text { nature } 1 .\end{array}$ \\
\hline $\begin{array}{l}\text { Pre-school Education } \\
\text { Department }\end{array}$ & $\begin{array}{l}\text { The order of the universe } 1 \text {, a human body } 1 \text {, mathematics } 1 \text {, the nature } 8 \text {, the harmony of the universe } 1 \text {, a rose } \\
\text { in the nature } 1 \text {, water } 2 \text {, a puzzle } 1 \text {, the night and the day } 1 \text {, a symmetry } 1 \text {, the outer appearance of an element } 1 \text {, } \\
\text { a rainbow } 1 \text {, the harmony and order } 1 \text {, a pattern } 1 \text {, a soul } 1 \text {, a camomile } 1 \text {, a gold ratio } 1 \text {, a painting } 1 \text {. }\end{array}$ \\
\hline \multirow[t]{2}{*}{$\begin{array}{l}\text { Primary Education } \\
\text { Department }\end{array}$} & An untouched nature 1 , looking at a nature view 1 , a tree 1 , the nature 1 , the sky 1 , a sea 1 , a honeycomb 1 . \\
\hline & Aesthetic concept emphasizing the expression of emotions within a person $(n=20)$ \\
\hline $\begin{array}{l}\text { Art Education } \\
\text { Department }\end{array}$ & The beauty within a person 1 . \\
\hline $\begin{array}{l}\text { Pre-school Education } \\
\text { Department }\end{array}$ & $\begin{array}{l}\text { The order of the inner beauty } 1 \text {, beauty } 1 \text {, a book } 2 \text {, painting a blank canvas } 1 \text {, a mirror } 4 \text {, a human being } 1 \text {, a } \\
\text { photo } 2 \text {, a beautiful picture } 1 \text {, a rotten apple } 1 \text {, a sea } 1 \text {, a melon } 1 \text {, robots } 1 \text {, a rose } 1 \text {. }\end{array}$ \\
\hline \multirow[t]{2}{*}{$\begin{array}{l}\text { Primary Education } \\
\text { Department }\end{array}$} & $\begin{array}{l}\text { A reflection of what we see and experience on us } 1 \text {, a light reflected from the world of imagination } 1 \text {, the } \\
\text { beauty of the nature } 1 \text {, tea } 1 \text {, reflecting the inner beauty } 1 \text {, the inner reflection of a person } 1 \text {. }\end{array}$ \\
\hline & The relative aesthetic concept that changes according to the person $(n=30)$ \\
\hline $\begin{array}{c}\text { Art Education } \\
\text { Department }\end{array}$ & A moving sky 1 , a changing canvas 1 , love 1 . \\
\hline $\begin{array}{l}\text { Pre-school Education } \\
\text { Department }\end{array}$ & $\begin{array}{l}\text { Fashion } 1 \text {, a personalized beauty } 1 \text {, an individualized beauty } 1 \text {, a relative concept } 1 \text {, mud } 1 \text {, a measurement } 1 \text {, } \\
\text { clouds } 1 \text {, the inner child } 1 \text {, the sky } 1 \text {, a personalized art } 1 \text {, a hobby } 2 \text {, a painting } 1 \text {, a camomile } 1 \text {, a rubber } 1 \text {, a } \\
\text { window } 1 \text {, a mirror } 1 \text {, the world } 1 \text {, a meal you do not know what it tastes like } 1 \text {, having breakfast in the view } 1 \text {, } \\
\text { an extraordinary beauty, pleasing to the eye } 1 \text {, pastry dough } 1 \text {, the perception of beauty changing from person } \\
\text { to person } 1 \text {, looking at the clouds } 1 \text {. }\end{array}$ \\
\hline \multirow[t]{2}{*}{$\begin{array}{l}\text { Primary Education } \\
\text { Department }\end{array}$} & The beauty that looks nice when we look at 1 , life 1 , a human being 1 , gymnastics 1 . \\
\hline & Aesthetic concept based on feeling pleasure $(n=67)$ \\
\hline $\begin{array}{l}\text { Art Education } \\
\text { Department }\end{array}$ & $\begin{array}{l}\text { Love } 2 \text {, the visual size of the concern } 1 \text {, the flexible body of a ballerina } 1 \text {, eating your favourite dish } 1 \text {, pleasure } \\
1 \text {, a bar of chocolate } 1 \text {, elegancy } 1 \text {, an explosion } 1 \text {, a heart addressing emotions } 1 \text {, anything eye-pleasing } 1 \text {, } \\
\text { watching a film } 1 \text {, impartial } 1 \text {, the feeling of pleasure } 1 \text {, the world } 1 \text {, a perfume } 1 \text {, a like, pleasure, a beauty } 1 \text {, } \\
\text { running in a spike field } 1 \text {, the nature } 1 \text {, all colours of the rainbow } 1 \text {, a delicious dish } 1 \text {, imagination } 1 \text {, }\end{array}$ \\
\hline $\begin{array}{l}\text { Pre-school Education } \\
\text { Department }\end{array}$ & $\begin{array}{l}\text { Excellence that looks nice } 1 \text {, art } 1 \text {, me } 1 \text {, a very green Black Sea highland } 1 \text {, a little child } 1 \text {, a stare into space } 1 \text {, } \\
\text { a scenery } 2 \text {, the delight in each human eye } 1 \text {, love } 1 \text {, nice jokes } 1 \text {, an emotion } 2 \text {, ourselves } 1 \text {, describing a word } \\
1 \text {, a heart-warming fondue } 1 \text {, a perfect looking painting } 1 \text {, a butterfly } 1 \text {, the sun } 3 \text {, the rhythm of music } 1 \text {, love } \\
1 \text {, a towel } 1 \text {, something that satisfies a person's sense of pleasure } 1 \text {, a smooth nose } 1 \text {, pleasing to the ear and eye } \\
1 \text {, a wind in a hot weather } 1 \text {, a rose } 2 \text {, a mountain view } 1 \text {, eating } 1 \text {, a tres leches cake } 1 \text {. }\end{array}$ \\
\hline \multirow[t]{2}{*}{$\begin{array}{l}\text { Primary Education } \\
\text { Department }\end{array}$} & $\begin{array}{l}\text { A life sweetening candy } 1 \text {, concrete } 1 \text {, a source of peace } 1 \text {, the spring } 1 \text {, slime } 1 \text {, a sea } 1 \text {, Neşet Ertaş songs } 1 \text {, a } \\
\text { beautiful rose } 1 \text {, a nice odour } 1 \text {, a moon } 1 \text {, the beauty in which we feel ourselves happy } 1 \text {, a delicious meal } 1 \text {, } \\
\text { fine details of life } 1 \text {, a bud } 1 \text {, our beloved ones } 1 \text {, spots of a ladybug } 1 \text {, a swan } 1 \text {, a cigarette } 1 \text {. }\end{array}$ \\
\hline & Aesthetic concept accepted as a science of beauty $(n=23)$ \\
\hline $\begin{array}{l}\text { Art Education } \\
\text { Department }\end{array}$ & $\begin{array}{l}\text { The science of beauty } 1 \text {, seeing and feeling } 1 \text {, look for the beauty } 1 \text {, a colourful flower } 1 \text {, better, more beautiful } \\
1 \text {, a flower } 1 \text {, a paradise filled with beauties } 1 \text {. }\end{array}$ \\
\hline $\begin{array}{l}\text { Pre-school Education } \\
\text { Department }\end{array}$ & $\begin{array}{l}\text { Beauty } 1 \text {, a spectacular football game } 1 \text {, the touch that beautifies the world } 1 \text {, a flower } 1 \text {, water } 1 \text {, describing } \\
\text { the sky to a blind } 1 \text {, a woman } 2 \text {, a leafy flower } 1 \text {, pleasing to the eye } 2 \text {, a poem } 1 \text {. }\end{array}$ \\
\hline \multirow[t]{2}{*}{$\begin{array}{l}\text { Primary Education } \\
\text { Department }\end{array}$} & $\begin{array}{l}\text { Beauty } 5 \text {, the revitalization of the nature in the spring } 1 \text {, Guernica } 1 \text {, eyes of a person } 1 \text {, the thing pleasing to the } \\
\text { eye } 1 \text {, an effort to present the beauty } 1 \text {, to look beautiful } 1 \text {. }\end{array}$ \\
\hline & The aesthetic concept that gives the person a different perspective $(n=14)$ \\
\hline $\begin{array}{l}\text { Art Education } \\
\text { Department }\end{array}$ & A different perspective 1 , looking at the life from a different angle 1 , different people come together 1 . \\
\hline $\begin{array}{l}\text { Pre-school Education } \\
\text { Department }\end{array}$ & $\begin{array}{l}\text { A perspective on life } 1 \text {, a rainbow } 1 \text {, pink glasses } 1 \text {, a quiet stream } 1 \text {, eye-glasses } 1 \text {, a sea } 1 \text {, a new life } 1 \text {, the sun } \\
1 \text {, an ink stain test } 1 .\end{array}$ \\
\hline $\begin{array}{l}\text { Primary Education } \\
\text { Department }\end{array}$ & iewpoint for the world 1 , the look of each person in the mirror 1 , falling in love 1 , the sun 1 . \\
\hline
\end{tabular}




\begin{tabular}{cl} 
Departments & \multicolumn{1}{c}{ Metaphors by Categories (n=219) } \\
\hline $\begin{array}{c}\text { Art Education } \\
\text { Department }\end{array}$ & Aesthetic concept that changes and beautifies the environment (n=25) \\
\hline $\begin{array}{c}\text { Pre-school Education } \\
\text { Department }\end{array}$ & $\begin{array}{c}\text { A change in a positive direction 1, a magic 4, a sparkle 1, the ripening of a fruit 1, harmony and elegancy 1, an } \\
\text { adjustment and change with no beginning and end 1, a modification 1, a restoration 1, a flower 1, a see 1, } \\
\text { multicoloured 1, wine 1, brushstrokes 1, being reborn 1, restoration 1, salvation 1, a tree on the prairie 1, a } \\
\text { picture frame 1, a child 1, a kite 1, a diamond 1. }\end{array}$ \\
\hline $\begin{array}{c}\text { Primary Education } \\
\text { Department }\end{array}$ & The life 1, rasped wood 1, Lokman Hekim's invention of Immortality Elixir 1. \\
\hline $\begin{array}{c}\text { Art Education } \\
\text { Department }\end{array}$ & Aesthetic concept bearing a vital importance (n=8) \\
\hline $\begin{array}{c}\text { Pre-school Education } \\
\text { Department }\end{array}$ & Aater 1. \\
\hline $\begin{array}{c}\text { Primary Education } \\
\text { Department }\end{array}$ & A pickle 1, water 1, bread 1, \\
\hline $\begin{array}{c}\text { Art Education } \\
\text { Department }\end{array}$ & Aesthetic concept as a surgical intervention (n= 4) \\
\hline $\begin{array}{c}\text { Pre-school Education } \\
\text { Department }\end{array}$ & A plastic surgeon 1, a revitalization of man 1, Ajda Pekkan 1. \\
\hline $\begin{array}{c}\text { Primary Education } \\
\text { Department }\end{array}$ & The National Lottery 1. \\
\hline
\end{tabular}

Metaphors generated in Table 4 are classified according to the departments and categories. Looking at this classification in general, it is observed that students of the Art Education Department produced metaphors in the aesthetic concept based on feeling pleasure category the most. Metaphors such as love (2), the flexible body of a ballerina (1), eating your favourite dish (1), pleasure (1), a bar of chocolate (1), elegancy (1), an explosion (1), anything eye-pleasing (1), watching a film (1), the feeling of pleasure (1) and a perfume (1) are some of the most obvious examples in this category. Meanwhile, examples such as an emotion (2), a butterfly (1), the sun (3), the rhythm of music (1), love (1), a towel (1), something that satisfies a person's sense of pleasure (1), a wind in a hot weather (1), a rose (2), a mountain view (1) and a tresleches cake (1) can be given for this category in which students of the Pre-school Education generated the most metaphors at the same time. Metaphors such as a sea (1), Neşet Ertaş songs (1), a beautiful rose (1), a nice odour (1), a moon (1), the beauty in which we feel ourselves happy (1) and delicious meal (1) take part among the examples that the students of the Primary Education generated for the same category. In the category of the aesthetic concept emphasizing the expression of emotions within a person, students express their opinion that the aesthetic is a more emotion-based concept. The students of the Art Education Department produced very few metaphors related to this category. The only metaphor generated in this area is the beauty within a person (1). Some of the metaphors generated by the students of the Pre-school Education Department can be listed as; the order of the inner beauty (1), beauty (1), a book (2), a painting a blank canvas (1), a mirror (4), a human being (1), a photo (2), a beautiful picture (1), a rotten apple (1), a sea (1) and a melon (1). In this section, the students of the Primary Education Department used the expressions of the beauty of the nature (1), tea (1), reflecting the inner beauty (1), as a metaphor. According to the metaphors generated by the students of the Art Education Department about the nature and the order of the universe, the beautiful and the ugly (1), the world (1), a colourful butterfly (1), a tree (1) and the nature (1) take part in the category of the aesthetic concept emphasizing the beauty in the nature with order, peace and harmony. Within the same category, the students of the Pre-school Education Department produced metaphors in the form of the order of the universe (1), a human body (1), mathematics (1), the nature (8) and the harmony of the universe (1). The metaphors of the students of the Primary Education in this category can be listed as a tree (1), the nature (1), the sky (1), a sea (1) and a honeycomb (1). For the category of aesthetic concept accepted as a science of beauty, it is observed that the theme of noticing the beauty consciously is the most common among the metaphors generated by the students of the Art Education Department. The metaphors generated here can be listed as the science of beauty (1), seeing and feeling (1), look for the beauty (1) and a paradise filled with beauties (1). Some of the metaphors that the students of the Pre-school Education Department generated under this category can be listed as a woman (2), a leafy flower (1), pleasing to the eye (2) and a poem (1). Some of the metaphors generated by the students of the Primary Education Department are beauty (5), the revitalization of the nature in the spring (1), Guernica (1) and pleasing to the eye (1). The metaphors that the students of the Art Education Department produced for the category of the relative aesthetic concept that changes according to the person can be seen as a moving sky (1), a changing canvas (1) and love (1). The students of the Pre-school 
Education Department used expressions such as the sky 1, a personalized art (1), a hobby (2), a painting (1), a camomile (1), a rubber (1), a window (1), a mirror (1), the world (1), having breakfast in the view (1), an extraordinary beauty, pleasing to the eye (1) and pastry dough (1). Metaphors produced by the students of the Primary Education Department in this category, on the other hand, are expressions such as life (1), a human being (1) and gymnastics (1). In the category of the aesthetic concept that gives the person a different perspective, expressions of looking at the life from a different angle (1) and different people come together (1) are among the metaphors produced by the students of the Art Education Department. Expressions such as a perspective on life (1), a rainbow (1) and pink glasses (1) are among the metaphors that the students of the Pre-school Education Department produced under this category. Expressions that the students of the Primary Education Department used, on the other hand, are the metaphors such as our viewpoint for the world (1), the look of each person in the mirror (1), falling in love (1) and the sun (1). There are very few metaphors generated by the students of the Art Education Department in the category of the aesthetic concept bearing a vital importance. The only metaphor generated in this area is water (1). It is possible to list concepts such as air (2), music (1), a kitchen (1) and piece completing the man (1) are among the metaphors generated by the students of the Pre-school Education Department. The metaphors that the students of the Primary Education Department also generated in the same field are a pickle (1), water (1) and bread (1). Under the category of the aesthetic concept that changes and beautifies the environment, the students of the Pre-school Education Department used expressions such as a magic (2), a sparkle (1), the ripening of a fruit (1), harmony and elegance (1), an adjustment and change with no beginning and end (1) a modification (1) and a restoration (1). On the other hand, the students of the Primary Education Department used expressions such as the life (1) and rasped wood (1) in this category. It is observed that the students of the Art Education Department haven't produced any metaphors in the categories of the aesthetic concept that changes and beautifies the environment and the aesthetic concept as a surgical intervention. The students of the Pre-school Education Department used expressions such as plastic surgeon (1), a revitalization of the man (1) and Ajda Pekkan (1) in the category of the aesthetic concept as a surgical intervention. The students of the Primary Education Department used only the metaphor of the National Lottery (1) in this category.

\section{Conceptual Categories}

Category 1: Generated metaphors related to the aesthetic concept emphasizing the beauty in the nature with order, peace and harmony

28 different metaphors, related to the aesthetic concept that emphasizes the beauty in the nature with order, peace and harmony, have been generated. It can be seen in Table 4 that metaphors such as "a colourful butterfly", "a tree", "the nature", "a puzzle", "the night and the day", "a symmetry" and "a honeycomb" were produced to describe the feature of emphasizing the beauty in the nature with order, peace and harmony of the aesthetic concept. The metaphor of "the nature" has been generated in the greatest number with the aim of describing the presentation of the harmony and order in the nature of the aesthetic concept. The main features of the metaphors in this category and the most obvious of the student expressions are listed as follows:

1. Everything that is natural: For Example; Everything that is natural (It' the order, the beauty in the nature) (Art, S3), Water (it's pure and clear.) (Pre-school, S126)

2. The harmony in the unity and solidarity on the earth: For example; The world (It's the cohesion in the unity and solidarity) (Art, S19), the order of the universe (similar to the universe, aesthetic also require harmony and order) (Pre-School, S77), A honeycomb (when you look at it, not only the honey that the bees do, but also the measured and beautiful shapes of the honeycombs attract the attention.) (Primary, S219), A human body (it has a perfect system like a human body) (Pre-school, S55), A pattern (things that are equal and repeat each other are beautiful and aesthetic) (S228).

3. Nature is visually beautiful. For example; The nature (Fascinating, perfect) (Pre-school, S57). A camomile (it looks nice, everything is proportional and at a dosage. It is far away from extravagance, simple and stylish, elegant.) (Pre-school, S243).

Category 2: Generated metaphors related to the aesthetic concept emphasizing the expression of emotions within a person.

20 different metaphors that emphasize the expression of emotions within a person of the aesthetic concept have been generated. It can be seen in Table 4 that metaphors such as "the order of the inner beauty", "a mirror", "a photo", "a melon", "tea", "reflecting the inner beauty" and "the inner reflection of a person" have been generated to describe the nature of aesthetic emphasizing the expression of emotions within a person. The metaphor "a mirror" has been produced at the greatest number to describe the aesthetic concept emphasizing the expression of emotions within a person. The main features of the metaphors in this category and the most obvious of the student expressions are listed as follows:

1. Aesthetic that reflects the inner beauty of a person: For example; The inner reflection of a person (it shows the thoughts, feelings, a person's inner world in other words) (Primary S216), A mirror (it reflects me) (Pre-school, S67). 
2. Aesthetic as expression: For example; $\boldsymbol{A}$ sea (Aesthetic provides the emergence of good emotions that exist in man) (Pre-school, S123), A photo (it shows how the image looks) (Pre-school, S92).

3. Aesthetic as a reflection of beautiful emotions: For example; The beauty within a person (you transfer it in the way that you live) (Art, S15), A beautiful picture (Pre-school, S97), The beauty of the nature (self-awareness, self-discovery) (Primary, S177).

\section{Category 3: Generated metaphors related to the relative aesthetic concept that changes according to the person}

30 different metaphors emphasizing that the concept of aesthetic is a relative situation that changes according to the individual have been generated. In Table 4, metaphors such as "the life", "gymnastics", "a moving sky", "a changing canvas", "fashion", "an individualized beauty", "a hobby", "a relative concept" and "mud" were produced in order to describe that aesthetic is a relative concept that changes according to the person. The metaphor of "hobby" has been produced at the greatest number with the aim of emphasizing that the aesthetic concept is a relative situation that changes according to the individual. The main features of the metaphors in this category and the most obvious of the student expressions are listed as follows:

1. 1-It varies from person to person: For example; $\boldsymbol{A}$ changing canvas (the thing everyone is trying to explain is different) (Art, S22), An individualized beauty (everyone has a different understanding of beauty) (Pre-school, S61), A moving sky (it changes according to perspective) (Art, S4) Gymnastics (There are exercises that everybody can do. They change according to the person.) (Primary, S216), The sky (it holds various kinds of beauties for everyone. Every perspective is a different view.) (Pre-school, S98).

2. 2-It shows change from age to age: For example; Fashion (it changes from person to person and from age to age) (Pre-school, S52). Having breakfast in the magnificent view of Black Sea. (Aesthetic changes according to the perception, culture, experience, interest and taste of the person. It is not just a concept related to art.) (Pre-school, S254).

\section{Category 4: Generated metaphors related to the aesthetic concept based on feeling pleasure}

67 different metaphors which emphasize that the concept of aesthetic is a phenomenon based on feeling pleasure have been produced. In Table 4, metaphors such as "love", "the flexible body of a ballerina", "eating your favourite dish", "pleasure", "a bar of chocolate", "an explosion", "a towel", "pleasing to the ear and eye", "a wind in a hot weather", "a rose", "a swan" and "a cigarette" have been generated to explain that aesthetic is a concept based on feeling pleasure. The metaphor of "love" has been produced in the most numerous number to emphasize that aesthetic is a concept based on feeling pleasure. The main features of the metaphors in this category and the most obvious of the student expressions are listed as follows:

1. Activate pleasant sentiments: For example; $\boldsymbol{A}$ life sweetening candy (there is aesthetic in everything, we all taste from what we look at see as long as we can see it.) (Primary, S166), A bar of chocolate (the more you eat, the more you want it) (Art, S17) A little child (it warms the inside of a person, and looks pleasant) (Pre-school, S71). The fondue that increases our appetite as we look at it (it is very sweet, there are fruits) (Pre-school, S107).

2. Arouse the feeling of pleasure: For example; $A$ nice odour (it is unforgettable, always on mind, gives pleasure) (Primary, S190), the flexible body movement of a ballerina (pleasure) (Art, S7), An explosion (that's what the images make you feel) (Art, S20). Love (it is excitement and pleasure, you need it.) (Art, S45).

\section{Category 5: Generated metaphors related to the aesthetic concept accepted as a science of beauty}

In this category, 23 different metaphors have been generated to define the aesthetic concept which is accepted as a science of beauty. In table 4 metaphors such as "the science of beauty", "pleasing to the eye", "woman", "beauty" and "Guernica" have been generated to explain that aesthetic is a concept accepted as a science. The metaphors of "pleasing to the eye" and "a woman" were produced in the most numerous numbers with the aim of emphasizing that the aesthetic is a concept accepted as the science of beauty. The main features of the metaphors in this category and the most obvious of the student expressions are listed as follows:

1. Investigate the beauty in art: For example; Seeing and Feeling (scientifically, the work is judged according to It) (Art, S11), Guernica (it is the effort to reach the unique one. Look for the beautiful and the original work for the self.) (Primary, S181).

2. Search for the beauty: For Example; Look for the beauty (it's a branch of science investigating the beauty) (Art, S21), Beauty (anything bearing aesthetic reflects the beauty.) (Primary, S169), Pleasing to the eye (a sense of aesthetic in human beings creates a sense of appreciation.) (Pre-school, S244).

Category 6: Generated metaphors related to the aesthetic concept that gives the person a different perspective

14 different metaphors that emphasize the aspect of the aesthetic concept that gives the person a different perspective have been generated in this category. In Table 4 , metaphors such as "the look of each person in the mirror", "falling in love", "pink glasses", "a quiet stream", "a 
different perspective" and "looking at the life from a different angle", were generated to emphasize the feature of the aesthetic concept giving the person a different perspective. The main features of the metaphors in this category and the most obvious of the student expressions are listed as follows:

1. Realize the beauty: For example; Pink glasses (aesthetic beautifies everything) (Pre-school, S113), A perspective on life (Aesthetic perception affects all of our lives.) (Pre-school, S60), Falling in love (As I look at the person I am love with, the word aesthetic comes into existence) (Primary, S200), The look of each person in the mirror (Looking at the beautiful, and the most important is being able to see it, which is a perspective, it always changes.) (Primary, S189), A sea (it hosts a lot of intertwined beauties; you need to look and see.) (Pre-school, S222).

2. Gain the ability to predict: For example; A different perspective (human beings interrogate themselves by different viewpoints) (Art, S12), Looking at the life from different angles (it expands your horizon, activates your thoughts).

\section{Category 7: Generated metaphors related to the aesthetic concept that changes and beautifies the environment}

In this category, 25 different metaphors which define the concept of aesthetic as changing and beautifying the environment have been generated. In Table 4, metaphors such as "a magic", "being reborn", "a restoration", "wine", "the life" and "rasped wood" were produced to describe the changing and beautifying the environment feature of the aesthetic concept. The metaphor of "magic" has been generated in the most numerous number to emphasize the changing and beautifying feature of the aesthetic concept. The main features of the metaphors in this category and the most obvious of the student expressions are listed as follows:

1. Show something different from it is: For example; A magic (aesthetic sees things different from it is or does something different from it is.) (Pre-school, S66), A diamond (the essence of the diamond is coal, but coal turns into diamond after various processes. The thing that turns coal to diamond is the aesthetic.) (Pre-school, S260)

2. Make a bad situation elegant, beautify it: For example; $\boldsymbol{A}$ change in a positive direction (it is delicacy, elegance, change.) (Pre-school, S50), rasped wood (the more you rasp it, the more beautiful it gets.) (Primary, S193).

\section{Category 8: Generated metaphors related to the aesthetic concept bearing a vital importance}

In this category, 8 different metaphors, which regard aesthetic concept as a vital importance bearing phenomenon, were produced. Table 4 shows that the metaphors such as "water", "air", "music", "a kitchen" and "a pickle" were produced to explain that aesthetic is a very important concept in human life. The metaphors of "air" and "water" are the most repeated metaphors in this category. The main features of the metaphors in this category and the most obvious of the student expressions are listed as follows:

1. Add vitality to life: For example; Water (it's a vital necessity.) (Art, S8), Air (things with high aesthetic values in our life give us happiness and joy to live. It is essential.) (Pre-school, S89), Water (it adds vitality and life to each area that it can reach.) (Primary, S188).

\section{Category 9: Generated metaphors related to the aesthetic concept as a surgical intervention}

In this category, 4 different metaphors, that define the concept of aesthetic as a surgical intervention, have been generated. In Table 4, metaphors such as "a plastic surgeon", "a revitalization of man", "Ajda Pekkan" and "the National Lottery" were produced to explain that aesthetic corresponds to a medical term. The main features of the metaphors in this category and the most obvious of the student expressions are listed as follows:

1. Change a disliked physical property: For example; The National Lottery (At any time the beauty can decay and at any time the beauty can occur.) (Primary, S193), Ajda Pekkan (she has aesthetic in every part of her body.), (Pre-school, S263), A revitalization of man (aesthetic recreates human beings from the beginning.), (Pre-school, S138), A melon (even if it looks nice outside, it may come out unripe.) (Pre-school, S137).

\section{Discussion and Conclusion}

The findings of the research are better understood when the reasons, which make the categorization, that the students provided when generating metaphors are examined. A good understanding of the reasons why the participants produced the metaphor provides an understanding of the full coverage of the presented concept in their minds. For this reason, they were also evaluated together with the metaphors in the examination carried out.

It is understood that the conceptual categories emerged about the concept of aesthetic change according to the numerical data and the intensity of art education the participants received. In general, the students who participated in the research perceived the concept of aesthetic in the same sense as feeling pleasure the most. In addition to this, it has been observed that students mostly accepted the beauty in the nature as artistic beauty and an element beautifying the physical structure of the environment. It has been observed that the students who participated in the research perceived the concept of aesthetic as a surgical intervention at the minimum rate. The distribution ratio of the categories according to the departments is shown in detail in the following chart. 


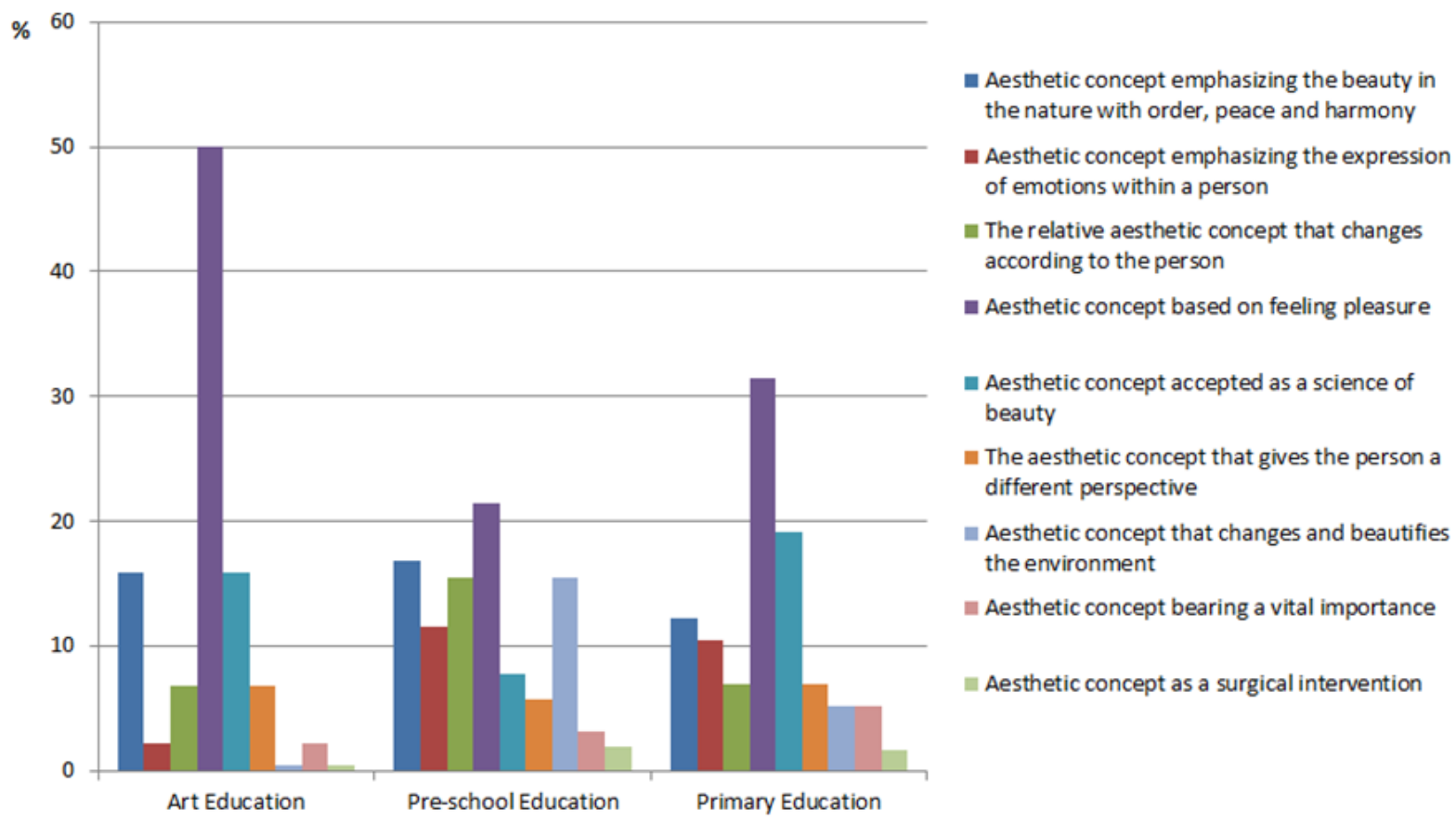

Figure 1. Distribution of Categories According to Departments

When we look at the differences of the perceptions regarding the aesthetic concept of different departments taking part in the research, the teacher candidates of the Art Education Department often describe aesthetic as a concept based on feeling pleasure and the beauty in the nature with order, peace and harmony. Meanwhile, the students in the same department also accept the concept of aesthetic as a field of science. However, this rate is less preferred comparing to the other categories. It may be possible to link the reason of the Art Education Department's students' low-ranking evaluations of aesthetic as a science to the lack of theoretical knowledge. Aesthetic is a philosophical concept and is based on different thought basis. Trying to explain aesthetic as a philosophy requires a scientific evaluation at the same time. This result is in line with the findings of [2]'s research, in which deficiencies in the perceptions of teacher candidates regarding the concept of philosophy are identified. In [4]'s research, It is determined that the students of the Fine Arts Education have different understandings about the concepts related to art. In addition to this, it turns out that students of the Art Education Department do not regard aesthetic as a concept that changes and beautifies the environment and as a surgical intervention. There are very few evaluations of the students of the Art Education Department in the categories that indicate that aesthetic is a concept emphasizing the expression of emotions within a person and bearing a vital importance.

It has been observed that teacher candidates of the Primary Education Department describe aesthetic as a concept based on feeling pleasure more often. Students of the Primary Education Department evaluated the concept of aesthetic as a field of science in the second row. It has also been observed there are students who perceive the concept of aesthetic as a surgical intervention in the Primary Education Department. It can be seen that the students of the Primary Education Department have very few opinions related to the aesthetic being a concept bearing a vital importance. This situation is expressed by "water" and "air" metaphors. This result differs from the finding that [21] obtained in his research, about primary school teachers defining the course of art education with the metaphor of "water" because it is needed in every area of life.

It has been observed that teacher candidates of the Pre-school Education Department describe aesthetic more as a concept based on feeling pleasure and meanwhile, the aesthetic concept emphasizing the beauty in the nature with order, peace and harmony is the second most frequently repeated concept. In the study conducted by [19], students in science classes tried to explain the textures they saw in the soil they were examining by using metaphors such as "spinach" and "diamond". In this study, it is concluded that learning through metaphors specially is strictly dependent on cognitive transformation; regardless of whether the aesthetic experience is positive or negative. The obtained results are similar to the results of this study. The Department of Pre-school Education is the department which defines aesthetic as a concept that changes and beautifies the environment the most. It is also observed that there are students of the Pre-school Education Department who perceive the concept of aesthetic as a surgical intervention. It is observed that the students of the Pre-school Education Department describe the concept of aesthetic as the expression of emotions within a person. It is seen that the students of the Pre-school Education 
Department have very few opinions related to the aesthetic concept bearing a vital importance. This situation is expressed by water and air metaphors.

Practices should be performed to interpret artworks in visual arts education courses aimed at aesthetic being an artistic concept with teacher candidates of the Pre-school Education Department. This training process should not be only in one semester in the third grade but also in both semesters of 3rd and 4th grades. Such arrangements may facilitate the formation of artistic likes of teacher candidates and it can also make it easier for them to understand the point of view of the artist. As the Pre-school education is the first step of the child to start his/her education life, the teacher's sensitivity to art and aesthetic can ensure that the child is related and sensitive to art from the very first childhood. Course contents and activities can be created about ensuring that teacher candidates of the Primary Education realize different aspects of art. Teacher candidates can be set to carry out applied studies at museums, art galleries and painting and sculpture workshops in order that they can apply them to their future students. It has been observed that the Art Education Department's students who take art education courses intensively accept the concept of aesthetic as the beauty in the nature and feeling of pleasure the most; on the other hand, they cannot associate it with philosophy. An elective course with this name can be arranged in the related undergraduate programs. This will help them to understand the background thinking of the artwork, to distinguish concepts between the beauty in the nature and the beauty in art, and to constitute a cognitive aesthetic understanding in students. In addition, activities that enable art educator candidates, who can serve as art counsellors in museums and galleries or in different units of state institutions, to perceive the historical and cultural structure of the environment they are in and to recognize discrepancies in environmental planning should be included in curricula.

As a result, the contents of art courses in the Departments of Primary and Pre-School Education can be further intensified both theoretically and practically. Interdisciplinary projects can be conducted to provide joint work between the Departments of Primary Education, Pre-School Education and Art Education.

\section{REFERENCES}

[1] Akhan, N. E. Sosyal bilgiler öğretmen adaylarının sanat algıları ve sanat konularının öğretimine yönelik görüşleri. Uşak Universitesi Sosyal Bilimler Dergisi, Özel Sayl, 146-162, 2013.

[2] Akkocaoglu, N., Yagci, E. Examination of Elementary Teachers Candidates' Perception of the concept of philosophy through metaphor analysis, Procedia - Social and Behavioral Sciences 46, 2383 - 2388, 2012.
[3] Berleant, A. Sensibility and Sense, The Aesthetic Transformation of the Human World. Exeter: Imprint Academy, USA: Imprint Academic Philosophy Documentation Center, 2010.

[4] Beyoglu, A., Ergin, Y.D. Güzel Sanatlar Eğitimi Bölümü Öğrencilerinin Mekân Kavramına İliş̧in Metaforik Algıları, Humanitas Uluslararası Sosyal Bilimler Dergisi, 6(11), 71-90, 2018.

[5] Boersema, D. Philosophy of Art Aesthetic Theory and Practice, United States of America: Westview Press, A Member of the Perseus Books Group, 2013.

[6] Bolat, Y. Perceptions of Classroom Teacher Candidates to the Turkish Education History Course: A Metaphor Analysis, Mustafa Kemal Üniversitesi Sosyal Bilimler Enstitüsü Dergisi, 14(38), 12-28, 2017.

[7] Bolla, P. Sanat ve Estetik, (Kubilay Koş, trans.).(2. Bask1). İstanbul: Ayrıntı Yayınları, 2012.

[8] Cazeaux, C. From Sensation to Categorization: Aesthetic Metaphor in Locke and Merleau-Ponty, Journal of Visual Art Practice, 4:2-3, 111-124, 2005.

[9] Clarken, R.H. Five Metaphors for Educators, American Educational Research Association, Chicago, 1997. http://rodclarken.files.wordpress.com/2011/09/five-metaph ors-for-educators.pdf

[10] Depew, D. Empathy, Psychology, and Aesthetic: Reflections on a Repair Concept. Iowa Research Online, 4 (1), 99-107. DOI: 10.13008/2151-2957.1033, 2005.

[11] Erişti Bedir, S. D. The Metaphoric Perception of Teacher Candidates Related 'Fine Arts Teacher' Concept. Inönü University Journal of the Faculty of Education, 18(1), 2017.

[12] Eroglu, A. John Dewey'de Deneyim ve Sanat, Doktora Tezi, Atatürk Üniversitesi, Sosyal Bilimler Enstitüsü, Erzurum, 2011.

[13] Forceville, C. Pictorial and multimodal metaphor in commercials. In E. F. McQuarrie, \& B. J. Phillips (Eds.), Go figure! New directions in advertising rhetoric, Armonk, NY: M.E. Sharpe, 178-204, 2008.

[14] Forceville, C."Non-verbal and multimodal metaphor in a cognitivist framework: Agendas for research." In: Gitte Kristiansen, Michel Achard, René Dirven and Francisco Ruiz de Mendoza Ibàñez (eds.), Cognitive Linguistics: Current Applications and Future Perspectives. Berlin/New York: Mouton de Gruyter, 379-402, 2006.

[15] Gadamer, H. G. Güzelin Güncelliği Oyun, Sembol ve Festival Olarak Sanat. (Fatih Tepebaş1l1, Trans.). (2.Bask1). İstanbul: Çizgi Kitabevi, 2017.

[16] Gültekin, F., Arıcıŏlu, A. Teacher Candidates' Metaphorical Perceptions of Older Family Members, Universal Journal of Educational Research 5(12): 2149-2159, 2017.

[17] Hamilton, E.R. Picture This: Multimodal representations of prospective teachers' metaphors about teachers and teaching, Teaching and Teacher Education 55, 33-44, 2016.

[18] Holt, D.K. The Search for Aesthetic Meaning in the Visual Arts, Bergin \& Garvey, Westport, USA, 2001. 
[19] Jakobson, B. Learning Science Through Aesthetic Experience in Elementary School, Aesthetic Judgement, Metaphor and Art, US-AB, Stockholm: Stockholm University, Printcenter, 2008

[20] Jensen, D. Metaphors as a bridge to understanding educational and social contexts. International Journal of Qualitative Methods, 5(1), 36-54, 2006.

[21] Kalyoncu, R. Sınıf Öğretmeni Adaylarının "Sanat Eğitimi Dersi" Kavramına İlişkin Metaforları. E-Journal of New World Sciences Academy Nwsa-Education Sciences, 8, (1), 90-102, 2013.

[22] Lakoff, G. Johnsen, M. Metaphors we live by. London: The University of Chicago Press, 2003.

[23] Lavazza, A. Art as a metaphor of the mind A neo-Jamesian aesthetic embracing phenomenology, neuroscience, and evolution, Phenom Cogn Sci 8:159-182, DOI 10.1007/s1 1097-008-9091-5, 2009.

[24] Loudermilk, M. L. The Use of Aesthetic in a Comprehensive Art Curriculum, Degree of Master of Art in Art Education, Graduate College Of Marshall University, Huntington, West Virginia, 2002.

[25] Maffesoli, M. The aesthetic problematic, Economy and Society, 26:1, 126-140, 1997. DOI: $10.1080 / 03085149700000007$

[26] McManus, I.C. Beauty is Instinctive Feeling: Experimenting on Aesthetic and Art, Schellekens, Elisabeth. and Goldie, Peter (Eds.), The Aesthetic Mind, Philosophy and Psychology. New York: Oxford University Press, 169-189, 2011

[27] Merriam, S.B. Nitel Araștırma Desen ve Uygulama Íçin Bir Rehber (3.bs.) [Qualitative research a guide to design and implementation (3th Ed.)] (Selahattin Turan, Trans.). Ankara: Nobel Yayıncılık, 2015.

[28] Milne, I. A Sense of Wonder, Arising from Aesthetic Experiences, Should be the Starting Point for Inquiry in Primary Science. Science Education International, 21 (2), 102-115, 2010.
[29] Morgan, G. Images of Organization. SAGE Publications, 2006.

[30] Morgan, G. Paradigms, Metaphors, and Puzzle Solving in Organization Theory, Administrative Science Quarterly, 25(4), 605-622, 1980.

[31] Rantala, V. Aesthetic Tension. Frankfurt: Peter Lang GmbH Internationaler Verlag der Wissenchaften, 2011.

[32] Saban, A. Primary School Teachers' and Their Students' Mental Images about the Concept of Knowledge, Elementary Education Online, Illköğretim Online, 7 (2), 421-455, 2008

[33] Schaeffer, J.-M. Aesthetic Relationship, Cognition, and the Pleasures of Art, Investigations into the Phenomenology and the Ontology of the Work of Art, Contributions To Phenomenology 81, 2015. DOI: 10.1007/978-3-319-14090-2 9

[34] Schiller, F. V. Estetik Üzerine, (1. Bask1). (Dr. Melahat Özgü, trans.). İstanbul: Kaknüs Yayınları, 1999.

[35] Skorczynska, H. Metaphor and education: Reaching business training goals through multimodal metaphor, Procedia - Social and Behavioral Sciences 116, 2344 2351,2014

[36] Sullivan, K. How Does Art 'Speak,' and What Does it 'Say?' Conceptual Metaphor Theory as a Tool for Understanding the Artistic Process, Thought Tools for A New Generation. Essays On Thought, Ideas, And The Power Of Expression, 81-89, 2006.

[37] Tunal1, İ. Estetik Beğeni, Çăgdaş Sanat Felsefesi Üstüne, (2. Bask1). İstanbul: Remzi Kitabevi, 2011.

[38] Wickman, P.-O. Aesthetic Experience in Science Education, Learning and Meaning-Making as Situated Talk and Action, Lawrence Erlbaum Associates, Publishers Mahwah, New Jersey, London, 2006.

[39] Yob, I. M. Thinking constructively with metaphors. Studies in Philosophy and Education, 22, 127-138, 2003. 